Prof. Ian Glenn
Research Fellow,
Department of
Communication Science,
University of the
Free State, Bloemfontein,
South Africa
Email : glennie@ufs.
ac.za
ORCID: https://orcid.
org/0000-0002-0893-
3118

DOl: https://dx.doi. org/10.18820/24150525/ Comm.v24.12

ISSN 2415-0525 (Online)

Communitas 2019 24:1-11

Date submitted:

2 October 2019

Date accepted:

1 November 2019

Date published:

12 December 2019

(c) Creative Commons With Attribution (CC-BY)
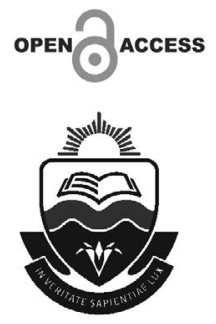

\section{AFRICA AND FOOTBALL: FIVE NOTES FOR MEDIA STUDENTS AND CULTURAL THEORISTS}

\begin{abstract}
Most analyses of African football have turned to neoliberalism and globalisation to explain developments, but these theories seem to lack analytical grip and predictive force. African teams have not improved their showing at FIFA World Cup tournaments over the past 30 years and in 2018 fared worse than in the past. South African comedian Trevor Noah's claim that Africa won the World Cup because of the presence of many non-white players in the French team conceals the reality that African football has entered a phase of reverse migration, with many national teams are composed to a large extent of European born and based players. South Africa's Premier Soccer League offers another problematic example: it is at once an example of successful broadcasting neoliberalism but raises problems in that its local success may be at the expense of successful globalisation of the game in South Africa. An examination of football viewership across sub-Saharan Africa may offer a better approach to understanding how sports partisanship and the ecology of leisure investment in sport works in a developing country, than theories from the Global North have.
\end{abstract}

Keywords: football; soccer; FIFA World Cup; neoliberalism; globalisation; Premier Soccer League; English Premier League; viewership; media studies; global south

\section{INTRODUCTION}

In 1998, shortly before France won the FIFA World Cup (hereafter World Cup) for the first time, French sociologist Pierre Bourdieu contrasted two notions of sport: a French notion of sport as local practice; and an American notion of sport as spectacle (Bourdieu 1998; Bourdieu et al. 2007). For Bourdieu (1998), televised sport was the Trojan Horse of the American neo-liberal model, given a decisive push in Europe by the 1995 Bosman ruling, treating sportsmen as individual entrepreneurs rather than as team or club members.

What should one make of Bourdieu's analysis over 20 years later, particularly as France won the World Cup a second 
time in 2018? And what of the role of Africa in the most global of games and televised spectacles in an era of globalisation? In particular, how convincing are arguments about neo-liberalism and globalisation and the role of Africa and African players in football globally given the developments since 1998 and, in particular, since the staging of the World Cup in South Africa in 2010 - an event that brought about a new spate of analysis and theorising about football in Africa? (Alegi \& Bolsmann 2009). Has the Trojan Horse of televised sport penetrated Africa completely and uniformly, or are there points of resistance and friction and national differences that suggest that other models may be more fruitful?

This article focuses on several issues to argue that old theoretical models no longer have much grip or explanatory power: the composition of African national teams and their success at international tournaments; the importance of national African leagues compared to international leagues; the question of recruitment and player movements from or within Africa; the viewership of national and international football across Africa; and the value of explanatory economic or cultural models.

\section{NOTE 1: WHO WON THE CUP?}

While there is always some danger in drawing major conclusions from sporting events in which luck, chance or apparently arbitrary factors may play a major role, the World Cup of 2018 certainly seemed to strengthen the argument, prominently made in Soccernomics, that European teams and a European logic of football are now more dominant than ever (Kuper 2014). No African team progressed beyond the group stages and the four semi-finalists (England, Croatia, Belgium and France) were all European countries. Even South American powers, like Brazil and Argentina, could not make it into the last four or even eight.

While Pelé's 1977 prediction that an African team would win the World Cup before 2000 has now been proven to be off the mark, Trevor Noah, South African born host of the USA Today Show, came to a different conclusion about the 2018 winners, France. In his show on 16 July 2018, he claimed jubilantly that, "Africa won the World Cup", pointing to the number of players of colour in the French team. His comments drew a swift rebuke from Gérard Araud, the French ambassador to the USA, who complained that France did not distinguish between French citizens but regarded them all as fully French (Butler 2018).

While this exchange and the identity politics involved drew some commentary, Noah's comments seemed to fit into older narratives about colonial or neo-liberal exploitation of African players by European powers (Maguire \& Pearton 2000). In this narrative, European powers, particularly France, win by buying in exceptional talents from Africa - in 1998, players such as Patrick Vieira, Marcel Desailly and Lilian Thuram had moved to France from Africa or the Caribbean to play football and drawn some resentment from right-wing French political figures (such as Jean-Marie Le Pen) who felt that the team was no longer a properly representative French team.

By 2018, however, Noah's comments were misleading. While England, Belgium and France all had significant representation of players who did not have a solely 
European heritage, very few of their players were born outside the countries they played for. England and Belgium had no players born in Africa, while Croatia had the most players born outside the country but qualifying on grounds of ancestry. France had, as the French ambassador remonstrated, only two of their 23-man squad born outside France and one of them had moved there as a young child.

The real story, it could be argued, was that the French system of sport as practice (that Bourdieu had praised) had helped form the successful French academies that were training a large number of inner-city children of migrants who ended up playing, not only for France, but for countries like Morocco (17 of their 23-man squad at the 208 World Cup were born in France), Algeria and Senegal from which their parents or grandparents had emigrated. This development was brought home even more dramatically in the 2019 African Cup of Nations (Afcon) final between Algeria and Senegal. Of the 23-man Algerian squad, 14 were born in France, while nine of the Senegalese squad were born there. Fully half of the players in the squads in the final of Africa's premier football tournament were thus born and trained in France. Trevor Noah would have spoken more truly had he said, "France won the Afcon Cup!"

When academic theorists look at what it takes to win the Afcon cup, it would no doubt be too simple to say, "have a large diaspora living in France", but this shift of team composition and power raises difficult questions for African football (Acheampong \& Akwaa-Sekyi 2019). What is wrong with training models and academies in Africa that stops the success of youth teams from the continent from into translating into the bigger global stage? What are the French (and Belgians and English) doing in developing young footballers that Africa is not able or willing to do? While one has to have some reservations about the success of many African teams in under-age competitions given the extent of deception about ages (Staff 2010), the bigger picture is undoubtedly one of poor or corrupt African management and foresight (Abbot 2018).

In the case of South Africa, in particular, the Premier Soccer League (PSL) benefits from generous corporate sponsorship and television rights, but sports development seems to receive minimal attention, at either the national or the club level. Promising developments, such as the University of Pretoria Academy, are left haphazardly to private enterprise or non-football educational facilities and lack sustainability over time and the 2010 World Cup's promise to help development by developing academies across Africa has left disillusionment nearly a decade later (Manzo 2012).

\section{NOTE 2: WHO IN AFRICA PLAYS WHERE?}

Another indication of the influence of European football on the African game is the strong correlation between the number of players from a particular African country playing in the top leagues in Europe and the success of their national teams in Afcon and World Cup competitions. For an observer like Gary Bailey, the unwillingness of South African players to move abroad and their preference to stay as big fish in a small pond limits the ability of the national team to compete on the continental or global stage (Bailey 2019). Other analysts have pointed to differing recruitment patterns and networks between countries like Ghana and South Africa (Darby \& Solberg 2009), 
while Dell'Oca suggests that Egypt and even the Democratic Republic of Congo are able, for differing financial and cultural reasons, to keep many top players at home and to strengthen local clubs - but at the expense of success in national competitions (Dell'Oca 2019).

These differing habits help shape loyalties and viewership (as will be explored further below) and also the success of club teams in continental competitions. The Egyptian and to some extent Tunisian and Moroccan preference for staying at home means that their clubs are far more successful in African club competitions that Ghanaian or Nigerian clubs, though the latter usually outperform in national competitions.

When Nigeria is second only to Brazil in providing players from outside Europe for the European leagues, the wide presence of Nigerian players in European leagues helps explain why Nigerian audiences prefer watching European football to local leagues or even national teams (Musa 2013; Dell'Oca 2019).

But why should players playing abroad be better? Is it that they are more driven, face tougher competition and need to be more resilient than local players, or are there other technical factors such as better tactical and strategic analysis, training regimes and psychological management? The comparison of South African soccer with rugby makes some differences clear.

Whatever the historical reasons for the different take up of soccer and rugby in South Africa (Hill 2009) or the reasons for the decline of white participation in soccer in South Africa in the professional sporting era (Venter 2016), clear differences emerge. In the case of rugby, some 200 South Africans, largely white, play professionally abroad, coaches often move to and from South Africa to other leading clubs or even national teams, teams draw on the expertise of other leading coaches in national tournaments, and local teams use cutting-edge computer software to help prepare and analyse games. The major regional rugby annual tournament in South Africa involves competition against teams from New Zealand, Australia and Argentina, not simply a national competition. At the 2019 Rugby World Cup, South African born players showed their mobility by representing nine countries (Namibia, Japan, Canada, Australia, Italy, France, USA, Scotland and Ireland) other than South Africa. South Africa ended up winning the tournament.

In the case of soccer, the move of coaches has very much been from Europe or even South America to Africa. Where does that leave the South African Premier Soccer League?

\section{NOTE 3: SOUTH AFRICA AND ITS PREMIER SOCCER LEAGUE}

In the heady early days of the new South Africa, the national team, Bafana Bafana, were allowed back into African competition and won the 1996 African Cup of Nations and followed that up by being runners-up in 1998. The SABC, the national public broadcaster, broadcast the games and also games from the PSL, the national soccer league.

In 2004, South Africa was awarded the rights to stage the 2010 World Cup, giving soccer unprecedented attention in a country where the dominant culture had always favoured rugby and cricket. For SuperSport, the sporting arm of Multichoice, the 
satellite broadcaster, it was obvious that the way to expand their appeal beyond middle-class white households lay in the passionate following that local soccer teams enjoyed. In 2007, SuperSport signed a deal with the PSL worth R1.6 billion, effectively ending not only the SABC's monopoly but also their rights to stage the most attractive derby matches. This development worked well for Multichoice, expanding their appeal and reach into a new black audience, and eventually cost the then head of the SABC his job for having lost these sports rights (Duncan \& Glenn 2010). With the influx of pre-World Cup sponsorship and television rights money, the PSL became one of the most well-funded in the world - various sources rate it as $7^{\text {th }}, 10^{\text {th }}$, or $15^{\text {th }}$ best internationally at the time.

Given Rupert Murdoch's dictum that "sport is the battering ram of pay TV", this was a classic neoliberal capture of the public space by private interests. While there are ongoing rights arguments given the SABC's parlous financial situation, the key development was that DSTV succeeded across sub-Saharan Africa in using football rights to infiltrate and change local markets - particularly in Nigeria and South Africa, but also in Kenya, the $\mathrm{DRC}$ and many other countries. Instead of being able to watch one game a week, African audiences now have, depending on which package they purchase from Multichoice, a range of African and European soccer viewing options. The quality and sophistication of camerawork and advertising of games has developed strongly.

As the increased funding for the PSL led to better salaries and greater prominence for the local league, players felt less incentive to move abroad to further their careers, leaving South Africa, perhaps like Egypt, with a flourishing local league with passionate followers, but a decline in performance continentally and internationally.

According to DSTV's analysis of audience preferences, in Africa it is only South Africans who prefer to watch the local league to watching international club football. The PSL thus has, despite decreased attendance at actual matches (Mathidza 2011), managed to hold onto a strong share of the viewing public, probably particularly through the national appeal of the leading clubs, Kaizer Chiefs, Orlando Pirates and Mamelodi Sundowns.

One South African club, however, seems to have understood and embraced the need to adapt to European norms in order to develop local talent to world standards. Mamelodi Sundowns, sponsored by oligarch Patrice Motsepe, is coached by former Bafana Bafana coach Pitso Mosimane, highly regarded by most local football journalists as a serious student of the game and successful coach (Gleeson 2019). In addition, they recently hired renowned Spaniard José Ramón Alexanko as director of academy and scouting, suggesting that they have accepted that longer term and more strategic investments may be necessary (Strydom 2019). South Africans have thus perhaps moved away from an English distrust of foreign managers and foreign methods, still prevalent a few decades ago, to trying to learn from the leading European clubs and training academies.

Within one country one thus sees two very different versions or inflections of neoliberalism and globalisation. For a fan of the PSL, one has a robust local cultural phenomenon, close to its roots and audiences, run by local owners, able to adapt over time, and competitive continentally as when Mamelodi Sundowns won the African club 
competition in 2016. For critics, the League's shortcomings are revealed whenever Bafana Bafana, the national men's team, has to compete in larger tournaments. In September 2019, the team, composed of players from the best-funded league in Africa, ranked a lowly $13^{\text {th }}$ among African teams, behind much smaller countries with lower budgets. While the PSL cannot be held responsible for all the faults of the South African Football Association, the organisation responsible for national teams, the financial muscle of the League does not translate into national competitiveness. Some critics point to the excessive power of leading owners and allege, off the record, that referees are bribed to ensure favourable results in key games. When Pitso Mosimane claims that he may need a sangoma to help ensure success in the MTN 8 competition in which Sundowns have been persistently unsuccessful, he may have been joking, but it also reinforces a stereotype of a league where superstition and magical thinking dominate over modern rationality (Fakude 2019). For other observers, many other PSL teams lag behind in up-to-date analysis and training methods (Stuart 2019).

Inevitably, perhaps, Bafana Bafana, after their poor international performances after their creditable showing in the 2010 World Cup, have drawn highly adverse comments from critics who expect the international success of the cricket or rugby teams, which have been and remained globally ranked among the best in the world. For these critics, many of them white, local soccer is of poor quality, "on a par with English First Division or Championship at best", and the national team's failure to qualify for successive World Cups has led to disengagement.

\section{NOTE 4: VIEWERSHIP, TALK SHOWS AND HOW TO INVOLVE PEOPLE}

Academic studies of football viewership and partisanship in Africa generally depend on short-term impressionistic accounts or personal reminiscences (Fletcher 2009; Jacobs 2009; Musa 2013). A more holistic account would probably emerge from the marketing and analysis departments of the SuperSport broadcaster who would be able to track trends over time. Unfortunately, most of their data is understandably confidential. Nonetheless, by going on some insights offered and the contributions of various expert commentators, the following issues emerge as critical.

The first is the language of broadcasts. The PSL in favouring African language commentators and keeping that distinctive offering in the DSTV era as an option remained closer to South African audiences than the rival English Premier League or foreign league broadcasts available only in English. As the use of English as a lingua franca in South Africa grows, one should expect a younger generation to drift away from the PSL - not only to other soccer leagues, but perhaps to other sports (Dell'Oca 2019). For the moment, however, the PSL remains a national African league that enjoys massive local support (figures for Egypt might show a similar trend but are not available).

The second issue is the importance of the talk surrounding soccer - notably in the predictions and post-match commentary and weekly talks shows by pundits with contributions from players and coaches. Bailey commented that African viewers generally prefer partisan passion and banter to more serious technical or strategic analysis. 
On DSTV, there is a crucial difference between talk about the English Premier League on DSTV with programmes such as The Football League Show hosted by Leroy Rosenior and local African shows. In the EPL shows, callers Skype in from around the world, with the majority of callers coming from Africa, but the callers are remarkably analytical, commenting on players' strengths and weaknesses, analysing tactical decisions by managers, and showing considerable knowledge of the Premier League and likely developments. The response from the hosts and guests in the studio is notably non-partisan and sympathetic to all clubs and loyalties, though some gentle banter is expected.

The effect of this programme and associated programmes, like the EPL Fantasy League, is to draw viewers into the total world of the EPL, a network of narratives that amounts to a kind of ongoing soap opera with complex plots and sub-plots and a next season guaranteed for all but an unlucky few. To belong to this world is to have to care deeply and knowledgably about it. While there is considerable good commentary on the PSL in local magazines like Kick Off or on local television, it seems a different kind of engagement from that with the EPL. Judging from those who appear on the show, it seems that most of the South African callers are white (often with strong audible English roots), Indian, Coloured or foreigners living in South Africa, but with an increasing number of black South Africans.

Musa's work in Nigeria highlighted the importance of television viewership in paid-for viewing venues, and reports from South Africa suggest that more work is needed on viewership in pubs and shebeens (Musa 2013). What matches are screened? How many games will a typical patron watch on a Saturday afternoon? What kinds of exchanges occur in that public space?

Speculatively, it may be that while the PSL offers many South Africans a chance to affirm local loyalty and belonging, the EPL offers many South Africans a model of a world open to the best talents where national origin no longer matters and where allegiance transcends locality, provinciality, or even nationality. For Coloured South Africans, in particular, the success of players like Quentin Fortune, Benni McCarthy and Steven Pienaar at leading English clubs at once showed up white claims to sporting superiority but also gave them a point of superiority over any local African league (Glenn \& Knaggs 2008).

While DSTV is understandably secretive with its viewership figures, its own advertisements and publicity suggest some trends. In a recent development to explain adding La Liga viewership to the DSTV Compact package, they suggest that the "purist PSL fan" is expanding viewership to include other European leagues. Moreover, the advertisement for this new development shows a black chef adding spicy Spanish ingredients to a dish, suggesting the wish to transform partisan viewers into sophisticated consumers.

Anthropological fieldwork would help ascertain whether (some? many? most?) local club fans are now being turned into consumers with a repertoire of club loyalties (one for the PSL, one for the EPL, one for La Liga, one for the Champions League, and so on) and what kind of emotional and intellectual investment each of these attachments 
involves. Understanding this allotment of sporting emotional and intellectual resources would go a long way to understanding the televisual ecology and reach and limitations of neoliberalism and globalisation.

\section{NOTE 5: THEORETICAL ISSUES}

Sports sociologists analysing soccer in general and African soccer in particular have tended to focus on broad theoretical concepts such as neoliberalism, globalisation and development (Maguire 1994; Maguire \& Pearton 2000; Giulianotti \& Robertson 2004; Dubal 2010; Eick 2010; Kennedy \& Kennedy 2012). Their concerns have generally been with the effects of neoliberalism, recruitment of elite players from Africa, or disputes about ownership and control - and they have generally avoided questions of viewership and local allegiances.

If one agrees with Connell and Dados that there are considerable advantages to studying globalisation and neoliberalism from the South rather than the North, one emerges with a different set of emphases, resistances and frictions (Connell \& Dados 2014). Africans have understood and suffered globalisation and neoliberalism and development more and longer than any Europeans. Africans with DSTV probably have a wider set of viewing choices than any European audience who do not have access to African football and whose viewing may be limited by local restrictions. Understanding developments in Africa may be more helpful than analysis from the Global North in predicting what will happen in China or Asia, or even South America, over time.

Older models of colonial exploitation or neoliberalism seem outdated in an era where Africa's contribution to European national teams seems to be historical and genetic, while Europe is providing the finished article for African use. Even a term like "glocalisation" does not address the real contradictions and differences viewers in Africa face. Neoliberalism controls the viewership of the PSL and the EPL alike in South Africa and across much of Africa, but when it covers everything, it may explain nothing. To return to Bourdieu, we have a world of viewership where the Trojan Horse of television has taken over, but that does not negate the importance of class distinctions, habitus, choices, changes in viewership habit and emotional attachments over time (Bourdieu 2013).

A crude version of neoliberalism says: it does not matter whether you watch Channel 203 or 204 on DSTV, the EPL or PSL, as you are a passive consumer paying DSTV for rights. But it is surely more logical to argue that there is a big difference in what and how you consume. As Musa points out in disagreeing with Rowe, this affects things like national sporting allegiances (Rowe 2003; Musa 2013) Moreover, in South Africa this can be seen as a clash that runs through debates on higher education, entertainment and the kind of society the country is or wants to be.

In South Africa, particularly, it seems that white South Africans (and many other minorities and some Africans) welcome the "hard" neoliberalism of international comparisons, standards, competition, and global rankings. A cricket or rugby team, university or business matters by showing its global competitiveness and strength. It seems black South Africans, perhaps like Egyptians, may prefer the local, which has 
meaning and history rather than the global product, which may be of a better standard but distant, alien.

Is it possible in the global neoliberal universe for a national soccer league to keep the kind of status Aussie Rules football enjoys in Australia or American football does in the USA? Can black South Africa carry on its undivided attention to the PSL or do the gods of neoliberalism inevitably drive all attention to the equivalent of a global colossus, a football Facebook or WhatsApp? Do declining attendances at local games reveal disillusion or simply a logical adaptation to a new televisual universe?

\section{CONCLUSION}

Bourdieu's 1998 argument on the tensions at the centre of modern sport needs revaluation. On the one hand, the American model of televised sport, the Trojan Horse, has diminished the appeal and power of sport as local practice. On the other hand, the ability of the French footballing authorities to harness that earlier tradition to create national training academies has, paradoxically perhaps, strengthened France's place in the neoliberal sporting universe. Old models of colonial or neoliberal exploitation may live on in Trevor Noah's witty quip about Africa winning the World Cup, but the reality of superior European training has to complicate any serious attempt to account for how sporting success is determined now and what neoliberalism and globalisation now mean.

The city the Trojan Horse captured has not been razed and all distinction eliminated. On the contrary, it has offered new spaces for kinds of difference and superiority, real or imagined, to emerge. From the Global South, neoliberalism and globalisation may have created patriotic fervour in some quarters and contempt elsewhere; led to increasing sporting attachment to clubs in some quarters, but to new detachments and a broader spread of involvement elsewhere.

Local African cultures need respect and examination in ways that theories from the Global North all too often ignore. Does neoliberalism thrive on difference or push for uniformity, does it push for greater attachment or floating and shifting and tenuous partisanship in a kind of emotional hedging of bets? To understand this, media and cultural scholars need to look further at viewership trends, social media responses, and to do the kind of anthropological fieldwork on viewing that will help understand the complex effects of sporting allegiance in Africa.

\section{REFERENCES}

Abbot, S. 2018. 'Why hasn't an African nation won the World Cup?' Africa is a Country. [Online]. Available at: https://africasacountry.com/2018/2006/why-hasnt-an-africannation-won-the-world-cup [Accessed on 3 November 2018].

Acheampong, E.Y. \& Akwaa-Sekyi, E.K. 2019. Want to put together a winning AFCON team? Here's the formula. The Conversation. [Online]. Available at: http://theconversation. com/want-to-put-together-a-winning-afcon-team-heres-the-formula-121650 [Accessed on 3 September 2018]. 
Alegi, P. \& Bolsmann, C. 2009. South Africa and the global game: Introduction. Soccer \& Society 11(1-2): 1-11. https://doi.org/10.1080/14660970903331284

Bailey, G. 2019. Interview. I. Glenn.

Bourdieu, P. 1998. L'État, l'économie et le sport. Sociétés \& Représentations 7(2). https:// doi.org/10.3917/sr.007.0013

Bourdieu, P. 2013. Distinction: A social critique of the judgement of taste. New York: Routledge.

Bourdieu, P. et al. 2007. The state, economics and sport. Culture, Sport, Society 1(2): 15-21. https://doi.org/10.1080/14610989808721813

Butler, B. 2018. Trevor Noah joked Africa won the World Cup. The French ambassador isn't happy. Washington Post. Washington DC.

Connell, R. \& Dados, N. 2014. Where in the world does neoliberalism come from? Theory and Society 43(2): 117-138. https://doi.org/10.1007/s11186-014-9212-9

Darby, P. \& Solberg, E. 2009. Differing trajectories: football development and patterns of player migration in South Africa and Ghana. Soccer \& Society 11(1-2): 118-130. https://doi.org/10.1080/14660970903331433

Dell'Oca, D. 2019. Interview. I. Glenn.

Dubal, S. 2010. The neoliberalization of football: Rethinking neoliberalism through the commercialization of the beautiful game. International Review for the Sociology of Sport 45(2): 123-146. https://doi.org/10.1177/1012690210362426

Duncan, J. \& Glenn, I. 2010. Turning points in South African television policy and practice since 1990. Pretoria: Unisa Press.

Eick, V. 2010. A neoliberal sports event? FIFA from the Estadio Nacional to the fan mile. City 14(3): 278-297. https://doi.org/10.1080/13604813.2010.482275

Fakude, E. 2019. Pitso: Maybe I need a good sangoma. Kickoff. Cape Town.

Fletcher, M. 2009. 'You must support Chiefs; Pirates already have two white fans!': Race and racial discourse in South African football fandom. Soccer \& Society 11(1-2): 79-94. https://doi.org/10.1080/14660970903331359

Giulianotti, R. \& Robertson, R. 2004. The globalization of football: a study in the glocalization of the 'serious life'. Br J Sociol 55(4): 545-568. https://doi.org/10.1111/j.1468-4446.2004.00037.x

Gleeson, M. 2019. Interview. I. Glenn.

Glenn, I. \& Knaggs, A. 2008. Field theory and tabloids. Power, politics and identity in South African media: 104-123.

Hill, L. 2009. Football as code: the social diffusion of 'soccer' in South Africa. Soccer \& Society 11(1-2): 12-28. https://doi.org/10.1080/14660970903331300

Jacobs, S. 2009. 'Itwasn'tthat I did notlike SouthAfrican football': media, history and biography. Soccer \& Society 11(1-2): 95-104. https://doi.org/10.1080/14660970903331409

Kennedy, P. \& Kennedy, D. 2012. Football supporters and the commercialisation of football: comparative responses across Europe. Soccer \& Society 13(3): 327-340. https:// doi.org/10.1080/14660970.2012.655503 
Kuper, S. 2014. Soccernomics: Why England loses, why Spain, Germany, and Brazil win, and why the US, Japan, Australia and even Iraq are destined to become the kings of the world's most popular sport. New York: Nation Books.

Maguire, J. 1994. Sport, identity politics, and globalization: Diminishing contrasts and increasing varieties. Sociology of Sport Journal 11(4): 398-427. https://doi. org/10.1123/ssj.11.4.398

Maguire, J. \& Pearton, R. 2000. The impact of elite labour migration on the identification, selection and development of European soccer players. Journal of Sports Science 18(9): 759-769. https://doi.org/10.1080/02640410050120131

Manzo, K. 2012. Development through football in Africa: Neoliberal and postcolonial models of community development. Geoforum 43(3): 551-560. https://doi.org/10.1016/j. geoforum.2011.10.006

Mathidza, S. 2011. Factors influencing football match attendance: the South African Premier League in crisis. Graduate School of Business. Cape Town, Cape Town. MBA.

Musa, M. 2013. The political economy of football viewership in Africa. Sport, Public Broadcasting, and Cultural Citizenship: Signal Lost?: 263.

Rowe, D. 2003. Sport and the repudiation of the global. International Review for the Sociology of Sport 38(3): 281-294. https://doi.org/10.1177/10126902030383002

Staff, O. 2010. Forever young: Nigerian football's age-old problem. Guardian. London.

Strydom, M. 2019. 'If I don't like it why am I at Sundowns?' asks Pitso Mosimane. Sowetan Live. Johannesburg.

Stuart, J. 2019. Interview. I. Glenn.

Venter, G.B. 2016. Gone and almost forgotten? The dynamics of professional white football in South Africa: 1959-1990. Unpublished doctoral thesis, University of Stellenbosch, South Africa. 